\title{
THE POSITION OF UNIVERSITY GRADUATES \\ IN THE LABOUR MARKET
}

\section{Michaela Jirotková}

\section{Summary}

The contribution deals with the situation of university graduates in the labour market, especially of those with hearing impairment.

\section{Keywords}

Graduate, hearing impairment, tertiary education, labour market.

\section{Resumé}

Př́spěvek se zabývá situací absolventů univerzitních studií na trhu práce, a to zejména těch, kteří mají sluchové postižení.

\section{Klíčová slova}

Absolvent, sluchové postižení, terciární vzdělávání, trh práce.

\section{Introduction}

In general, the successfully completed level of education has quite a significant effect on one's success in the labour market. The level of education increases the rate of economical activity and, on the contrary, decreases the unemployment rate. People of higher education and qualification are better employable, and therefore less prone to unemployment.

Young university graduates (up to 30 years) are slightly worse than university graduates in general, since they are entering the labour market and have no experience nor work history, and they only have mediate contacts. Their unemployment rate is therefore higher than in all university graduates and it often reaches the same level as the total unemployment. ${ }^{1}$ It is even more visible in differences among countries. In the Czech Republic, the unemployment rate

\footnotetext{
${ }^{1}$ Better are those graduates, in almost all countries, who had worked with their employers working whilst on during the course of study.
} 
of university graduates up to 30 years of age is around $5 \%$; even lower it is, for example, in Ireland, Finland and the Netherlands. However, for example, in Italy or in Greece every fifth or sixth graduate up to 30 years of age is unemployed. In view of the overall weak labour market the same applies to university graduates in Poland. ${ }^{2}$

In the labour market, university graduates with hearing impairment form a particular risk group. In addition to the general problem of unemployment of graduates, these face obstacles associated with difficulties in oral communication. However, there are also problems resulting from lack of social understanding between the aurally disabled and hearing colleagues at work. ${ }^{3}$

It happens that students of hearing impairment are interested in a certain interest but after the completion of their studies they do not work in the field. Qualified graduates come to an environment where the suitability or unsuitability of the chosen university major will show. This will prove only after the start of a graduate's working process. In case of failure in seeking a job the graduates lose motivation for professional self-realization, or are unwilling to take over the responsibility for their own lives. Their lack of practice, missing work habits and minimum experienceare a disadvantage in applying for a job. Great attention is paid to active involvement of graduates in the labour market, in particular through consultancy systems and tools of active employment policy.

Tarcsi (in Jesensky, 1998, p. 145) states that generally it can be said that the deaf people are able to work in various working sectors but no special attention is paid to the questions closely related to this issue, e.g. keeping a job, the subordinate/superior relation, searching for a new job, opportunities for qualification and retraining, the possibility of termination of a joband its consequences. The problems that may arise for a deaf employee at the workplace are the result of:

- limited understanding or using the colloquial language by colleagues and the employer,

- lack of knowledge of the standards of the "hearing culture" and values relevant for the organization of work,

- difficult access to "random" information as a result of hearing impairment.

Work and the resulting material security is an important prerequisite for involvement of hearing-impaired persons in the hearing society. The resolution of

\footnotetext{
${ }^{2}$ Processed according to http://www.natur.cuni.com/www/data/student/doc/pdf uplatneni. [Online].

${ }^{3}$ Processed according to http://www.vupsv.cz/Cervenkova_odb_priprava.pdf.
} 
these problems, however, cannot be accidental and, according to Tarcsi (1995), not at the charitable level. It requires the cooperation of experts and certainly founding special centres that will deal with such issues.

\section{THE DEFINITION OF A GRADUATE - JOB SEEKER}

Currently the employment offices monitor three indicators related to the number of unemployed graduates: ${ }^{4}$

\section{All registered graduates - job seekers}

Graduates - job seekers, as defined by the Ministry of Labour and Social Affairs, now used only for statistical purposes, are the job seekers who are natural persons under 25 years of age, graduated two years ago as maximum; the university graduates only up to the age of 30 .

\section{Available unemployed graduates}

The number of available the unemployed graduates represents the number "all the graduates - job seekers minus those graduates who cannot immediately start working".

\section{Unemployed "recent" graduates}

Unemployed recent graduates include only those who finished their education in the period immediately prior to the term of the count, i.e. the count in April. These are the graduates who successfully finished their studies in the period from May $1^{\text {st }}$ to April $30^{\text {th }}$ of the year of the count.

\section{PROFESSIONAL AND KEY COMPETENCES}

The graduates choose their position in the labour market on one hand on the basis of the focus of their vocational (i.e. professional) training but in the end the graduates' position is determined mainly by the requirements of the labour market. In other words the graduates choose from the opportunities the labour

\footnotetext{
${ }^{4}$ Chamoutová D., Burdova, J.: Nezaměstnanost absolventi̊ škol se středním a vyšším odborným vzděláním, p. 13.

${ }^{5}$ These are the jobseekers who may who may immediately start working when offerred a suitable job, i.e. the registered unemployed who do not have any objective obstacle to a job. The jobseekers not considered available are those who are arrested, incapable for work, those participating in retraining courses or those performing a short-time job and those receiving maternal subsidy or social security income during maternity leave.
} 
market has to offer. The graduate's actual position in the labour market thus can be very different from their own ideals and it may not even correspond to their vocational training (underqualified work or work out of the scope of training).

From the viewpoint of successful entry of the hearing disabled graduates to the labour market it is important to what extent their real abilities, skills and knowledge (competence) correspond to those required by the employers. "Competences possessed by employees and job seeker in various extend can be divided into professional and key competences. The professional competences are closely related to a particular qualification and their mastering enables (or facilitates) the exercise of certain professions or occupations. With the growing importance of qualifications exceeding individual professions and the changing work requirements the emphasis put on the key competences increases as well. The key (transferable) competences are such knowledge, abilities and skills, which appear necessary for the success not only in the labour market but also in everyday life."

What applies to all graduates is that employers prefer employees with work experience. On the other hand, employers like mainly young people, and this not only because of saving on their salaries, but primarily because that in this way they can train the employees according to their requirements and needs. A number of employers prefer graduates in some cases. The reasons stated are following: ${ }^{7}$

- being unburdened with previous work habits,

- language skills,

- computer skills,

- willingness to learn,

- overall rejuvenation of the collective,

- future replacement of retired workers,

- contribution in the form of new views and solutions.

Sometimes there are also conditional reasons. Graduates are preferred only if they have had some experience or a part-time-job experience in the sector they are accepted for.

Mastering these competences should contribute to the ability to perform various professional tasks or to switch among different professions without

${ }^{6}$ Kalousková P.: Potřeby zaměstnavatelů a prripravenost absolventů škol - šetření v terciární sfére, p. 7.

${ }^{7}$ Kalousková P.: Potřeby zaměstnavatelů a pripravenost absolventů škol - šetření v terciární sfére, p. 9. 
major problems and to help match capabilities of employees and requirements of employers.

\section{ARTICULATION OF THE TERTIARY SYSTEM TO THE LABOUR MAR- KET $^{8}$}

A close interconnection between the field of employers and the educational system represents one of the paths leading to a balance of the quality of fresh workforce and the requirements of the labour market. The most frequent forms of cooperation between employers and school are students' excursions and visits to workplaces, students' study stays evaluated by employers, participation in research or other projects of particular schools, job offers advertised at schools, proposing, supervising and opposing diploma theses, or seminar papers, participation in job fairs, paid study stays or cooperation in development and research projects.

The institutional structure and political framework interconnecting the Czech tertiary institutions and the labour market, have its strengths defined below.

\section{Strengths}

some public universities have study programmes, lessons and research interconnected to practice,

$>$ private universities and higher technical schools are more oriented to employability and the graduates' success in the labour market,

$>$ the national policy framework, created by the Ministry of Education, Youth and Sports, contains some elements forcing institutions of tertiary education to focus on employability of their graduates and their success in the labour market,

$>$ a priority of the Ministry of Education, Youth and Sports is cooperation between universities and their regions and various employers, connection of theory and practice in university education.

\footnotetext{
${ }^{8}$ Processed according to http://www.msmt.cz/uploads/bila_kniha/OECD_Country_Note_ CZ_celek. Pdf [Online].
} 


\section{Weaknesses}

The institutional structure and political framework of the Czech tertiary education also have their weaknesses in the context of the labour market.

Institutional structure

$>$ even though new universities have started up, the balance between demand and offer is still not optimal, because a lot of students with school-leaving examination will not be accepted to get to university,

$>$ universities are not fully adapted to the task of providing students education and at the same time preparing suitable for practice; university institutions are working only for themselves and do not see the need to enter into the wider society and working life.

\section{Summary}

To compare the Czech system of tertiary education with the formally binary system that is in Finland or the Netherlands, as well as with the formally unitary university system that exists in the United Kingdom, the Czech Republic has relatively few graduates prepared for the practice. "In Finland and the Netherlands study $47 \%$ respective $67 \%$ of students, where the schools provide professionally-oriented education with training on the basis of practical activities." In the United Kingdom and other formally unitary systems most students also study at higher education institutions that are focused largely on the professionally-oriented education. In the Czech Republic too many students of public universities study too long and, above it, in programs that do not prepare them for practice.

To support the success of graduates, even those with hearing disability, in the labour market it is inevitable to emphasize mainly:

- obtaining competences and their development, adjusting the profile of student to the needs of the labour market,

- the need for the design of study programmes that enable students to acquire competences and knowledge according to their choice during their studies.

\section{References}

GAVORA, P. Úvod do pedagogického výzkumu. Brno: Paido, 2000. ISBN 8085931-79-6.

JESENSKÝ, J. Podstata integrace handicapovaných. In Integrace - znamení doby. Praha: Karolinum, 1998. ISBN 80-7184-691-0.

\footnotetext{
${ }^{9}$ http://www.msmt.cz/uploads/bila_kniha/pdf OECD_Country_Note_CZ_celek.
} 


\section{Web sources}

ČERVENKOVÁ, A., KOTÍKOVÁ, J. Odborná př́prava zdravotně postižené mládeže a její uplatnění na trhu práce [online], [quoted 27. dubna 2009]. Available in World Wide Web: http://www.vupsv.cz/Cervenkova_odb_priprava. pdf.

CHOMOUTOVÁ D., BURDOVÁ J. Nezaměstnanost absolventů škol se středním a vyšším odborným vzděláním [online], [quoted 27. 4. 2009]. Available in World Wide Web: http://www.infoabsolvent.cz/TematickyKatalog/FStranka. aspx?CiloveSkupiny=4\&KodStranky=9.0.20.

KALOUSKOVÁ P. Potřeby zamèstnavatelù a pripravenost absolventů škol - šetrení v terciární sfére [online], [quoted 29.4.2009]. Available in World Wide Web: http://www.infoabsolvent.cz/TematickyKatalog/FStranka.aspx?CiloveSkupiny $=4 \&$ KodStranky=9.0.04.

Ústav pro informace ve vzdělání: Bílá kniha - národní program rozvoje vzdělání v České republice [online], [quoted 29. 4. 2009]. Available in World Wide Web: http://www.msmt.cz/dokumenty/bila-kniha-narodni-program-rozvoje-vzdelavani-vceske-republice-formuje-vladni-strategii-v-oblasti-vzdelavanistrategie-odrazicelospolecenske-zajmy-a-dava konkretni-podnety-k-praci-skol.

Mgr. Michaela Jirotková,

student of the Department of Special Pedagogy,

Palacký University, Olomouc,

Žižkovo nám. 5,

77140 Olomouc 


\section{APPENDIXES}

Table 1 Weaknesses of the interconnection of the tertiary system to the labour market

\begin{tabular}{|c|c|}
\hline OECD Countries & Czech Republic \\
\hline $\begin{array}{l}\text { there are politics of tertiary education, } \\
\text { which can be used to support the inter- } \\
\text { connections of the tertiary education to } \\
\text { the labour markets by means ofmanage- } \\
\text { ment, funding, performance and quality }\end{array}$ & $\begin{array}{l}\text { - only relatively few policies are created } \\
\text { with this aim }\end{array}$ \\
\hline $\begin{array}{l}\text { - in many tertiary systems cooperation of } \\
\text { the tertiary institutions and the institu- } \\
\text { tions of the labour market (companies, } \\
\text { trade unions and professional associa- } \\
\text { tions) is based on the role these partici- } \\
\text { pants play in the management of the } \\
\text { institutions of tertiary education }\end{array}$ & $\begin{array}{l}\text { - in the boards there are external agents } \\
\text { represented only on a small scale and } \\
\text { the influence of these boards on stra- } \\
\text { tegic decision making of the Czech } \\
\text { universities is also limited }\end{array}$ \\
\hline $\begin{array}{l}\text { - in some countries there are national data } \\
\text { registers that make it possible to get a } \\
\text { compact and long-term idea of success } \\
\text { in the labour market by interconnecting } \\
\text { data of students and data of wages and } \\
\text { positions of graduates } \\
\text { - in other countries each institution of ter- } \\
\text { tiary education is obliged to monitor and } \\
\text { publish information of the career of their } \\
\text { graduates in the labour market }\end{array}$ & $\begin{array}{l}\text { - the institutions of tertiary education } \\
\text { are not obliged to keep track of the } \\
\text { career of their graduates in the labo- } \\
\text { ur market and to report it } \\
\text { - the ministry supported an analysis of } \\
\text { university graduates' success in the la- } \\
\text { bour market according to study pro- } \\
\text { grammes and institutions by funding } \\
\text { the relevant project }\end{array}$ \\
\hline $\begin{array}{l}\text { - the ministry may consider the requirements } \\
\text { of the labour market while evaluating the } \\
\text { applications of new study programmes (i.e. } \\
\text { will there be demand for graduates from } \\
\text { the presented programme?) or evaluating } \\
\text { the quality of the current programmes is } \\
\text { the programme focused on the develop- } \\
\text { ment of employability?) }\end{array}$ & $\begin{array}{l}\text { - accreditations and re-accreditations } \\
\text { concentrates on "the ability of the in- } \\
\text { stitution to provide programs in requi- } \\
\text { red quality" (primarily on staffing the } \\
\text { programme with academic person- } \\
\text { nel), and not on the labour market } \\
\text { needs nor graduates' employability }\end{array}$ \\
\hline $\begin{array}{l}\text { one of the parameters of the methodolo- } \\
\text { gy of funding of institutions may be suc- } \\
\text { cess in the labour market }\end{array}$ & $\begin{array}{l}\text { - it has a very well constructed metho- } \\
\text { dology of funding of institutions, ho- } \\
\text { wever success in the labour market as } \\
\text { a criterion is not applicable }\end{array}$ \\
\hline
\end{tabular}

Source: Ministry of Education, Youth and Sports http://www.msmt.cz/uploads/bila_kniha/OECD_Country_Note_CZ_celek.pdf. 